\title{
Photosynthetic efficiency of Clusia arrudae leaf tissue with and without Cecidomyiidae galls
}

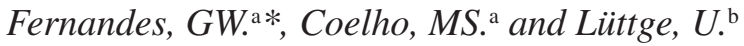 \\ ${ }^{a}$ Ecologia Evolutiva e Biodiversidade, Departamento de Biologia Geral - DBG, Instituto de Ciências Biológicas - ICB, \\ Universidade Federal de Minas Gerais - UFMG, CP 486, CEP 30161-970, Belo Horizonte, MG, Brazil \\ 'Institute of Botany, Darmstadt University of Technology, Schnittspahnstr. 3-5, D-64287 Darmstadt, Germany \\ *e-mail: gw.fernandes@gmail.com \\ Received March 11, 2009 - Accepted November 9, 2009 - Distributed October 31, 2010
}

(With 2 figures)

\begin{abstract}
Leaf galls induced by a still undescribed new species of Cecidomyiidae (Diptera) are frequent on leaves of Clusia arrudae Planchon \& Tirana (Clusiaceae) in the rupestrian fields at $1400 \mathrm{~m}$ a.s.l. in Serra do Cipó, Minas Gerais, Brazil. Galls were $7.1 \pm 0.7 \mathrm{~mm}$ in diameter, one chambered with only one larva inside. Gall tissue is green and soft. Assessments of photosynthetic capacity using chlorophyll- $a$ fluorescence measurements revealed that photosynthetic performance of gall tissue and healthy leaf tissue were rather similar. Hence, the morphological changes due to gall development were not associated with significant changes in the photosynthetic capacity of the tissue.
\end{abstract}

Keywords: insect galls, herbivore impact, photosynthesis.

\section{Eficiência fotossintética do tecido foliar de Clusia arrudae Planchon \& Tirana com e sem galhas de Cecidomyiidae}

\begin{abstract}
Resumo
Galhas induzidas por uma espécie nova ainda não descrita de Cecidomyiidae (Diptera) são frequentes nas folhas de Clusia arrudae Planchon \& Tirana (Clusiaceae) em áreas de campos rupestres a 1400 metros de altitude na Serra do Cipó, Minas Gerais, Brasil. As galhas apresentaram um diâmetro médio de 7,1 \pm 0,7 mm e uma loja com uma larva dentro. As galhas são verdes e de tecido macio. Análises da capacidade fotossintética usando medidas de fluorescência da clorofila a revelaram que o desempenho fotossintético dos tecidos da galha e sadios foi similar. Assim, as mudanças induzidas pelo desenvolvimento das galhas não foram associadas a mudanças significativas da capacidade fotossintética do tecido.
\end{abstract}

Palavras-chave: galhas de insetos, impacto de herbívoros, fotossíntese.

\section{Introduction}

Herbivore impacts upon plants may range from harmful to positive (Belsky, 1986; Hendrix, 1979; Whitham et al., 1991; Paige and Whitham, 1987; Belsky et al., 1993; Cornelissen and Fernandes, 2001a,b) and vary according to herbivore type (Mattson et al., 1988). Gall inducing insects represent a special guild that develops in host plant meristematic tissues, where the gall-forming larvae modify the tissue growth processes, transforming the attacked cells into a gall structure that provides improved food and shelter for the larvae (Rohfritsch and Shorthouse, 1982; Ferreira et al., 1990; Price et al., 1987). Although galling insects are mostly considered true parasites of their host plants (Price et al., 1986, 1987), a spectrum of impact of gallers upon their host plants has been reported (Andrade et al., 1995; Fernandes, 1987).
Insect galls can cause important changes in host plant physiological processes. Galls are known to alter both carbon transport and allocation patterns of the plant, sometimes distant from the gall (Denill, 1985; Souza et al., 2001; Fay et al., 1996b; Fernandes, 1987; Fernandes et al., 1993; Sacchi et al., 1988). As an example, stem galls induced by the gall midge Rhopalomyia hypogaea on Chrysanthemum leucanthemum caused damage to the attacked stem and also reduced the production of the capitulum's ray florets (Mani, 1964). Gall induction on apical meristems may lead to the activation of dormant lateral meristems, affecting flower and fruit production secondarily (Craig et al., 1986; Fay and Hartnett, 1991; Silva et al., 1996). Insect gall growth and maintenance drain resources from the host plant and ultimately reduce flower head production 
and/or decrease seed viability (Hartnett and Abrahamson, 1979; Fernandes and Ribeiro, 1990; Fernandes et al., 1993; Fay et al., 1996a). Numerous studies have shown that galls operate as physiological sinks for nutrients and assimilates, modifying tissues that otherwise could serve for growth and reproduction (Fourcroy and Braun, 1967; Janckiewicz et al., 1970; Kirst and Rapp, 1974; McCrea et al., 1985; Larson and Whitham, 1991; Fay et al., 1996a). Some galling cynipids (Hymenoptera) and cecidomyiids (Diptera) control the secondary metabolism of gall tissues, concentrating tannins and phenolics in the peripheral parenchyma, thereby leaving a highly nutritive inner layer consumed by the galling larva (Mani, 1964; Rohfritsch and Shorthouse, 1982). Because the sinks manipulated by gallers are physiologically linked to photosynthetic carbon fixation processes, galler impacts on leaf-level photosynthetic processes would be expected. In fact, gallers have been associated with both increased and decreased net leaf carbon gain (Fay et al., 1993; Larson, 1998). Net photosynthetic rates reflect the outcome of the dark and light and carboxylation reactions of photosynthesis. To date, there have been few studies examining these components independently with respect to insect galls (Fay et al., 1993; Larson, 1998; Florentine et al., 2005; Lemos Filho et al., 2007).

Chlorophyll- $a$ fluorescence is a measure of the efficiency of the photosynthetic light utilisation in the light reactions with different applications, such as ecophysiology and crop productions (Baker and Rosenqvist, 2004; Lemos Filho et al., 2004). In this study, we compared the photosynthetic capacity of galled and healthy leaf tissue of Clusia arrudae Planchon and Tirana (Clusiaceae), measuring chlorophyll- $a$ fluorescence parameters, on site, in the field. Clusia is the only genus of trees, sensu stricto, which has the Crassulacean acid metabolism (CAM). This special metabolism and the flexibility in the carbon acquisition under varying conditions are considered as ecophysiological advantages. Furthermore, the existence of ecotypes in high ecological amplitudes is associated with high rates of speciation within the genus (Lüttge, 2006).

Our hypothesis is that differences in the photosynthetic capacity between health and gall tissues do not exist, corroborating the argument proposed by Price et al. (1987) describing the vascular tissue from other parts of the plant as responsible for supplying the nutritional larvae requirements.

\section{Material and Methods}

\subsection{Study site}

The present study was performed in a rupestrian field vegetation area, at $1400 \mathrm{~m}$ a.s.1., in Serra do Cipó, located at the Southern portion of the Cadeia do Espinhaço, Minas Gerais State, Brazil (19 $12^{\prime} \mathrm{S}$ and $\left.43^{\circ} 29^{\prime} \mathrm{W}\right)$. The Serra do Cipó is dominated by cerrado and rupestrian field vegetation (Eiten, 1978; Giulietti et al., 1987). Clusia arrudae occurs on the rocky outcrops of the area, in soils with low water retention capacity, low concentration of nitrogen and phosphorus, and high aluminium concentration (Marques et al., 2002). The climate is characterised by rainy summers and dry winters, with high temperatures during the day, which, mainly during the winter, decrease drastically at night (Madeira and Fernandes, 1999). The habitat where $C$. arrudae occurs is also exposed to a highlight incidence (GWF, unpub. data).

\subsection{Description of the system}

The leaf galls on $C$. arrudae are induced by a still undescribed species of Cecidomyiidae (Diptera) and are found all year around. They are green and one-chambered, with only one larva inside. Galls are more or less globoid, with the most pronounced portion on the abaxial leaf surface (Figure 1). Adult galling insects emerge from the adaxial portion of the gall, as observed by the emergence hole left on the gall walls (Figure 1). One to seven galls could be found on the leaf laminae during the study period (average of $2.6 \pm 0.7$ galls per leaf, $n=30$ ). Galls occur singly, and coalescence was rarely observed. Galls averaged $7.15 \mathrm{~mm}$ in diameter when occurring singly $(\mathrm{SE} \pm 0.87, \mathrm{n}=30)$. Parasitism by an unidentified species of wasp on the gall midge was also observed but not quantified.

\subsection{Sampling}

Measurements of chlorophyll $a$ fluorescence parameters were performed in the afternoon (from 3:00 PM to 4:00 PM) of a bright day in October 2002 on green gall tissue and adjacent tissue (hereafter called healthy tissue) of one leaf of three plants, totaling three (3) leaves of $C$. arrudae. The chlorophyll- $a$ fluorescence measurements were performed using a miniaturised pulse-amplitude modulation fluoremeter, Mini-PAM (H. Walz. Effeltrich, Germany) equipped with a standard 2030-B leaf clip holder (Bilger et al., 1995). Measurements of photosynthetic photon flux density (PPFD) $(\lambda=400-700 \mathrm{~nm})$ were taken by the micro-quantum sensor of the leaf clip calibrated against a LI-COR 190 quantum sensor (Li-COR, Lincoln, NE, USA).
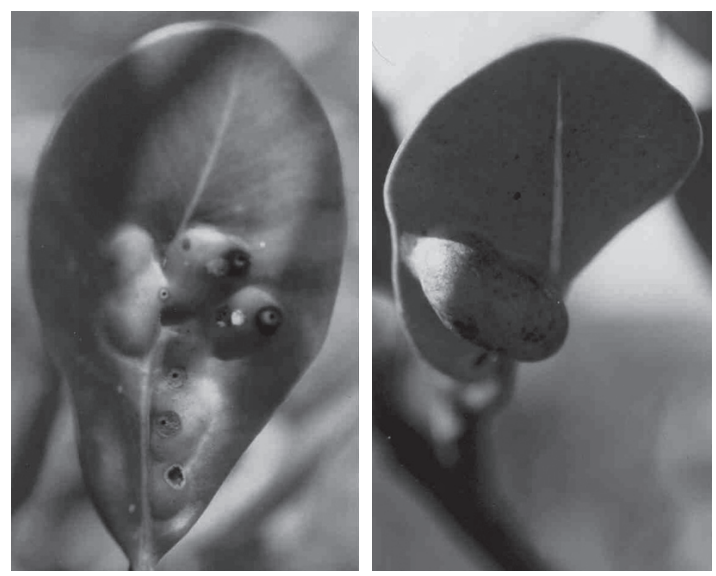

Figure 1. Leaves of C. arrudae with galls of an undescribed species of Cecidomyiidae showing green gall tissue and the adjacent leaf tissue of which chlorophyll fluorescence parameters were measured. 


\subsection{Data analysis}

The effective quantum yield of PSII $\left(\Delta \mathrm{F} / \mathrm{F}_{\mathrm{m}}{ }^{\prime}\right)$ was calculated as $\left(\mathrm{F}_{\mathrm{m}}{ }^{\prime}-\mathrm{F}\right) / \mathrm{F}_{\mathrm{m}}$, , where $\mathrm{F}$ is the fluorescence yield of the light-adapted sample and $\mathrm{F}_{\mathrm{m}}$ ' is the maximum fluorescence obtained when a light pulse of $800 \mathrm{~ms}$ duration (intensity $\approx 3000 \mu \mathrm{mol} \cdot \mathrm{m}^{-2} \cdot \mathrm{s}^{-1}$ ) is superimposed on the prevailing environmental light level (Schreiber and Bilger, 1993). Instant light-response curves of $\Delta \mathrm{F} / \mathrm{F}_{\mathrm{m}}$, were obtained using the light-curve programme of the Mini-PAM, where actinic light intensity was increased during 4 minutes in eight steps following each other after 30 seconds (Rascher et al., 2000). The internal halogen lamp of the instrument, using the fibre-optics and the leaf-clip holder, provided the light. Apparent electron transport rate was obtained as $\mathrm{ETR}=0.5 \times 0.84 \times\left(\Delta \mathrm{F} / \mathrm{F}_{\mathrm{m}}{ }^{\prime}\right) \times \mathrm{PPFD}$. The factors in the equation for the ETR stand for an equal distribution of excitation energy to both photosystems I and (0.5) II, and for an assumed average light reflection of $16 \%(0.84)$ (Rascher et al., 2000).

\section{Results and Discussion}

Tissue temperature was $30^{\circ} \mathrm{C}$ and ambient photosynthetic photon flux density (PPFD) c. $1000 \mu \mathrm{mol} . \mathrm{m}^{-2} . \mathrm{s}^{-1}$ during measurements (Table 2). At this PPFD photosynthetic performance, i.e. effective quantum yield $\left(\Delta F / F_{m}{ }^{\prime}\right)$ and apparent electron transport rate (ETR) were similar for both the galled and the non-galled tissue (Table 1). Comparison with light-dependence curves (Figure 1, Table 2) shows that

Table 1. Effective quantum yield $\left(\Delta \mathrm{F} / \mathrm{F}_{\mathrm{m}}{ }^{\prime}\right)$ of PSII and apparent photosynthetic electron transport rate (ETR, $\left.\mu \mathrm{mol} . \mathrm{m}^{-2} . \mathrm{s}^{-1}\right)$ at ambient photosynthetic photon flux density $\left(\mathrm{PPFD}, \mu \mathrm{mol} \mathrm{m} \mathrm{m}^{-2} \mathrm{~s}^{-1}\right.$ ) and temperature $\left(\mathrm{T},{ }^{\circ} \mathrm{C}\right)$ for gall tissue and adjacent healthy leaf tissue of $C$. arrudae $(\overline{\mathrm{x}} \pm \mathrm{sd}$, $\mathrm{n}=3$ ).

\begin{tabular}{ccc}
\hline & Healthy tissue & Gall tissue \\
\hline $\mathrm{PPFD}$ & $905 \pm 230$ & $1040 \pm 145$ \\
$\Delta \mathrm{F} / \mathrm{F}_{\mathrm{m}}$, & $0.20 \pm 0.06$ & $0.18 \pm 0.07$ \\
$\mathrm{ETR}$ & $76 \pm 27$ & $76 \pm 25$ \\
$\mathrm{~T}$ & $30.4 \pm 0.6$ & $30.2 \pm 0.7$ \\
\hline
\end{tabular}

Table 2. Cardinal points of light response curves (Figure 2) of gall tissue and adjacent healthy leaf tissue of $C$. arrudae. ETR $_{\text {max }}$ is the apparent maximum electron transport rate. $\mathrm{PPFD}_{\text {sat }}$ and $\mathrm{PPFD}_{50}$ are the PPFD at $\mathrm{ETR}_{\text {max }}$ and at $1 / 2 \mathrm{ETR}_{\max }$, respectively. $\Delta \mathrm{F} / \mathrm{F}_{\mathrm{m}}{ }^{\prime}$-sat and $\Delta \mathrm{F} / \mathrm{F}_{\mathrm{m}}{ }^{\prime}-50$ are the effective quantum yield at $\mathrm{PPFD}_{\text {sat }}$ and $\mathrm{PPFD}_{50}$, respectively. PPFD and ETR are in $\mu$ mol. $\mathrm{m}^{-2} \cdot \mathrm{s}^{-1}(\overline{\mathrm{x}} \pm \mathrm{sd}, \mathrm{n}=3$ leaves $)$.

\begin{tabular}{ccc}
\hline & Healthy tissue & Gall tissue \\
\hline $\mathrm{PPFD}_{\text {sat }}$ & $1230 \pm 230$ & $1900 \pm 100$ \\
$\mathrm{PPFD}_{50}$ & $250 \pm 30$ & $420 \pm 185$ \\
$\mathrm{ETR}_{\text {max }}$ & $120 \pm 15$ & $120 \pm 15$ \\
$\Delta \mathrm{F} / \mathrm{F}_{\mathrm{m}}{ }^{-}{ }^{-\mathrm{sat}}$ & $0.23 \pm 0.06$ & $0.14 \pm 0.02$ \\
$\Delta \mathrm{F} / \mathrm{F}_{\mathrm{m}}{ }^{-}-50$ & $0.57 \pm 0.09$ & $0.35 \pm 0.09$ \\
\hline
\end{tabular}

this PPFD ambient was close to saturation for the healthy and galled tissue. Although saturating PPFD was higher for the galled as compared to the healthy tissue, maximum ETR (ETR ${ }_{\text {max }}$ ) was similar and effective quantum yield of PSII even somewhat lower (Table 2). An inspection of the curves (Figure 2) and their cardinal points (Table 2) suggests, however, that at lower light intensities the healthy tissue has a somewhat superior performance compared to the galled tissue. At half saturating PPFD, $\Delta F / F_{m}$ ' is a little higher in the healthy than in the galled tissue.

The major result of the present measurement of photosynthetic capacity is the somewhat unexpected observation that photosynthetic performance of galled and healthy tissue was rather similar. It is clear that the morphological changes due to gall development were not associated with significant changes in the photosynthetic capacity of the tissue. Fay et al. (1993) reported increased leaf photosynthesis, stomatal conductance, and water potential over ungalled shoots in galls induced by Antistrophus silphii Gillete 1891 (Hymenoptera: Cynipidae) on Silphium intergrifolium Michx. (Asteraceae). Furthermore, galled plants experienced a smaller drop in leaf photosynthesis and stomatal conductance over a 4-day period after watering. The authors argued that while other guilds of herbivores consume the area of the attacked plant organ, galling insects leave their host organs intact. In addition, they argue that the gall-induced increase in leaf photosynthesis can be interpreted as a compensatory response by the plant, lessening the negative effect of galls on plant performance. Other measurements reported that the presence of galls caused a negative impact on photosynthesis when compared to the rates of healthy tissues (Larson, 1998; Florentine et al., 2005). They suggested that sink competition for nutrients between healthy leaves and gall tissue may account for the negative impacts on photosynthetic rates. In the same way, Lemos-Filho et al. (2007) did not find significant changes in photosynthetic activity between galled and ungalled tissues. However, they found changes in stomatal conductance due to the insect galling attack which can cause a decrease in carbon absorption, causing direct impacts on plant growth.

High concentrations of nitrogen, carbon and minerals in gall tissue were reported in many studies (Paquete et al., 1992; Raman et al., 2006). Morphological changes due to gall development were not associated with significant changes in the photosynthetic capacity of the tissue in this experiment. As the photosynthetic activity of the gall tissue is not increased to supply the needs of gall developing, our data support the hypothesis of adaptive value for insects by nutritional improvements, where these invertebrates control the nutrient levels in galls to their own benefit and the photosynthetic energy needed to supply gall growth and development may be being redirected from other host plant regions (Price et al., 1987).

Nonetheless, more studies on the physiology of gall induction throughout gall development and on the impact on their host plants are needed for a better understanding of the plant response to gall formation. 

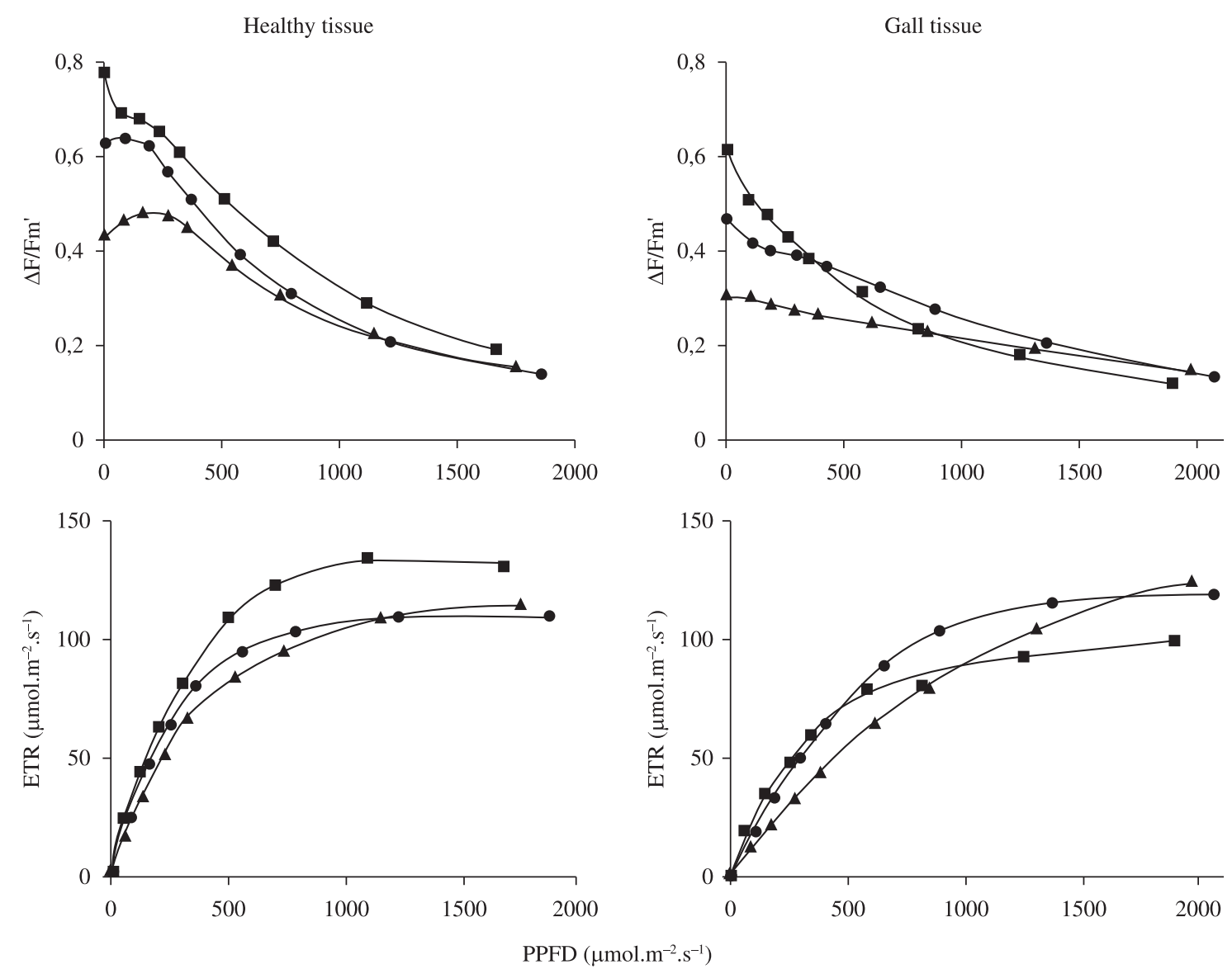

Figure 2. Light dependence (PPFD) curves of gall tissue and adjancent healthy tissue of $C$. arrudae with effective quantum yield $\left(\Delta \mathrm{F} / \mathrm{F}_{\mathrm{m}}{ }^{\prime}\right)$ of PSII and apparent photosynthetic electron transport rate (ETR).

Acknowledgements - This study was supported by the Volkswagen Foundation (grant no, 1/77 310), CNPq (309633/2007-9, 476178/2008-8), FAPEMIG (EDT-465/07, APQ-01278/08), and Parque Nacional da Serra do Cipó IBAMA.

\section{References}

ANDRADE, GI., IVONEIDE, MS., FERNANDES, GW. and SCATENA, VL., 1995. Aspectos biológicos das galhas de Tomoplagia rudolphi (Díptera: Tephritidae) em Vernonia polyanthes (Asteraceae). Revista Brasileira de Biologia = Brazilian Journal of Biology, vol. 55, no. 4, p. 819-829.

BAKER, NR. and ROSENQVIST, E., 2004. Applications of chlorophyll fluorescence can improve crop production strategies: an examination of future possibilities. Journal of Experimental Botany, vol. 55, no. 403, p. 1607-1621.

BELSKY, AJ., 1986. Does herbivory benefit plants? A review of the evidence. American Naturalist, vol. 127, no. 6, p. 870-892

BELSKY, AJ., CARSON, WP., JENSEN, CL. and FOX, GA., 1993. Overcompensation by plants: herbivore optimization or red herring? Evolutionary Ecology, vol. 127, no. 1, p. 109-121.

BILGER, W., SCHREIBER, U. and BOCK, M., 1995. Determination of quantum efficiency of photosystem II and of non-photochemical quenching of chlorophyll fluorescence in the field. Oeoclogia, vol. 102 , no. 4 , p. 425-432.

CORNELISSEN, TG. and FERNANDES, GW., 2001a. Induced defenses to herbivory: effects of damage-induced changes on leaf quality and insect herbivore attack. Trees, vol. 15, no. 4, p. $236-241$

CORNELISSEN, TG. and FERNANDES, GW., 2001b. Defense, growth, and nutrient allocation in Bauhinia brevipes (Leguminosae)? Austral Ecology, vol. 26, no. 3, p. 246-253.

CRAIG, TP., PRICE, PW. and ITAMI, JK., 1986. Resource regulation by a stem-galling sawfly on the arroyo willow. Ecology, vol. 76, no. 2, p. 419-425.

DENILL, GB., 1985. The effect of the gall wasp Trichilogaster acaciaelongifoliae (Hymenoptera: Pteromalidae) on reproductive potencial and vegetative growth of the weed Acacia longifolia. Agriculture, Ecosystems and Environment, vol. 14, no. 2, p. 53-61.

EITEN, G., 1978. Delimitation of cerrado concept. Vegetation, vol. 36 , no. 3 , p. $169-178$.

FAY, PA. and HARTNETT, DC., 1991. Constraints on growth and allocation patterns of Silphium integrifolium (Asteraceae) caused by a cynipid gall wasp. Oecologia, vol. 88, no. 2, p. 243-250. 
FAY, PA., HARTNETT, DC. and KNAPP, AK., 1993. Increased photosynthesis and water potentials in Silphium integrifolium galled by cynipid wasps. Oecologia, vol. 93, no. 1, p. 114-120.

FAY, PA., HARTNETT, DC. and KNAPP, AK., 1996a. Plant tolerance of gall-insect attack and gall-insect performance. Ecology, vol. 77, no. 2, p. 521-534.

FAY, PA., PRESZLER, RW. and WHITHAM, TG., 1996b. The functional resource of a gall-forming adelgid. Oecologia, vol. 105, no. 2, p. 199-204.

FERREIRA, AS., FERNANDES, GW. and CARVALHO, LG., 1990. Biologia e história natural de Euphalerus ostreoides (Homóptera: Psyllidae) cecidógeno de Lonchocarpus guilleminianus (Leguminosae). Revista Brasileira de Biologia = Brazilian Journal of Biology, vol. 50, no. 2, p. 417-423.

FERNANDES, GW., 1987. Gall-forming insects: their economic importance and control. Revista Brasileira de Entomologia, vol. 31, no. 3, p. 379-398.

FERNANDES, GW. and RIBEIRO, SP., 1990. Plant response to herbivory: two examples from the neotropics. Ecotropicos, vol. 3 , no. 2 , p. $77-86$.

FERNANDES, GW., SOUZA, AFL. and SACCHI, CF., 1993. Impact of a Neolasioptera (Diptera: Cecidomyiidae) stem galler on its host plant, Mirabilis linearis (Nyctaginaceae). Phytophaga, vol. 5 , p. 1-6.

LEMOS FILHO, JP., CHRISTIANO, JCS. and ISAIAS, RMS., 2007. Efeitos da infestação de insetos galhadores na condutância e taxa relativa de transporte de elétrons em folhas de Aspidosperma australe Müell. Arg. E de A. spruceanum Benth. ex Müell. Arg. Revista Brasileira de Biociências, vol. 5, no. 2, p. 1152-1154.

LEMOS FILHO, JP., GOULAR, MF. and LOVATO, MB., 2004. Chlorophyll fluorescence parameters in populations of two legume trees: Stryphnodendron adstringens (Mart.) Coville (Mimosoideae) and Cassia ferruginea (Schrad.) Schrad. ex DC. (Caesalpinoideae). Revista Brasileira de Botânica, vol. 27, no. 3, p. 527-532.

FLORENTINE, SK., RAMAN, A. and DHILEEPAN, K., 2005. Effects of gall induction by Epiblema strenuana on gas exchange, nutrients, and energetics in Parthenium hysterophorus. BioControl, vol. 50, no. 5, p. 787-801.

FOURCROY, M. and BRAUN, C., 1967. Observations sur la galle de l'Aulax glechomae L. sur Glechoma hederacea L. II. Histologie et role physiologique de la coque sclérifiée. Marcellia, vol. 34, p. 3-30.

GIULIETTI, AM., MENEZES, NL., PIRANI, MM. and WANDERLEY, MGL., 1987. Flora da Serra do Cipó, Minas Gerais: caracterização e lista das espécies. Boletim de Botânica, vol. 9, p. 1-151.

HARTNETT, DC. and ABRAHAMAON, WG., 1979. The effects of stem gall insects on life history patterns in Solidago canadensis. Ecology, vol. 60, no. 5, p. 910-917.

HENDRIX, SD., 1979. Compensatory reproduction in a biennal herb following insect defloration. Oecologia, vol. 42, p. 107-118.

JANCKIEWICZ, LS., FITCH, H. and ANTOSZEWSKI, M., 1970. Preliminary studies on the translocation of 14C-labelled P4 towards the gall evoked by Cynipis (Diplolepis) quercus-folii L. on oak leaves. Marcellia, vol. 36, p. 363-372.
KIRST, GO. and RAPP, H., 1974. Zur physiologie der Galle von Mikiola fagi Htg. auf Blattern von Fagus silvatica L. II. Transport ${ }^{14} \mathrm{C}$ markierter Assimilate aus dembefallenen Blatt und aus Nachbarblattern in die Galle. Biochemistry and Physiology Pflanz, vol. 165, p. 445-455.

LARSON, KC., 1998. The impact of two gall-forming arthropods on the photosynthetic rates of their hosts. Oecologia, vol. 115, no. 2, p. 161-166.

LARSON, KC. and WHITHAM, TG., 1991. Manipulation of food resources by a gall-forming aphid: the physiology of sink-source interactions. Oecologia, vol. 88, no. 1, p. 15-21.

LÜTTGE, U., 2006. Photosynthetic flexibility and ecophysiological plasticity: questions and lessons from Clusia, the only CAM tree, in the neotropics. New Phytologist, vol. 171, no. 1, p. 7-25.

MADEIRA, JA. and FERNANDES, GW., 1999. Reproductive phenology of sympatric species of Chamaecrista (Leguminosae) in Serra do Cipó, Brazil. Journal of Tropical Ecology, vol. 15, p. 463-479.

MANI, MS., 1964. The ecology of plant galls. The Hague: Junk.

MARQUES, AR., FERNANDES, GW., REIS, IA. and ASSUNÇÃO, RM., 2002. Distribution of adult male and female Baccharis concinna (Asteraceae) in the rupestrian fields of Serra do Cipó, Brazil. Plant Biology, vol. 4, p. 94-103.

MATTSON, WJ., LEVIEUX, J. and BERNANRD-DAGAN, C., 1988. Mechanisms of woody plant defenses against insects: search for pattern. New York: Springer-Verlag.

McCREA, KD., ABRAHAMSON, WG. and WEIS, AE., 1985. Goldenrod ball gall effects on Solidago altissima: 14C translocation and growth. Ecology, vol. 66, no. 6, p. 1902-1907.

PAIGE, KN. and WHITHAM, TG., 1987. Overcompensation in response to mammalian herbivory: the advantage of being eaten. American Naturalist, vol. 129, no. 3, p. 407-416.

PAQUETE, LC., BAGATTO, G. and SHORTHOUSE, JD., 1992. Distribution of mineral nutrients within the leaves of common dandelion (Taraxacum o.cinale) galled by Phanacis taraxci (Hymenoptera: Cynipidae). Canadian Journal of Botany, vol. 71, p. 1026-1031.

PRICE, PW., ROININEN, H. and TAHVANAINEN, J., 1986. Plant age and attack by the bud galler, Euиra mисronata. Oecologia, vol. 73 , no. 3, p. 334-337.

PRICE, PW., WARING, GL. and FERNANDES, GW., 1987. Hypotheses on the adaptive nature of galls. Proceedings of the Entomological Society of Washington, vol. 88, no. 1, p. 361-363.

RAMAN, A., MADHAVAN, S., FLORENTINE, SK. and DHILEEPAN, K., 2006. Metabolite mobilization in the stem galls of Parthenium hysterophorus induced by Epiblema strenuana inferred from the signatures of isotopic carbon and nitrogen and concentrations of total non-structural carbohydrates. Entomologia Experimentalis et Applicata, vol. 119, no. 2, p. 101-107.

RASCHER, U., LIEBIG, M. and LÜTTGE, U., 2000. Evaluation of instant light-response curves of chlorophyll fluorescence parameters obtained with a portable chlorophyll fluorometer on site in the field. Plant, Cell and Environment, vol. 23, no. 12, p. 1397-1405. 
ROHFRITSCH, O. and SHORTHOUSE, JD., 1982. Insect galls. In KAHL, G. and SCHELL, JS. Molecular biology of plant tumors. New York: Academic Press. p. 131-152.

SACCHI, CF., PRICE, PW., CRAIG, TP. and ITAMI, JK., 1988. Impact of shoot galler attack on sexual reproduction in the arroyo willow. Ecology, vol. 69, no. 6, p. 2021-2030.

SCHREIBER, U. and BILGER, W., 1993. Progress in the chlorophyll fluorescence research: major developments during the last years in retrospect. Progress in Botany, vol. 54, p. 151-173.

SILVA, IM, ANDRADE, GI, FERNANDES, GW. and LEMOS FILHO, JP., 1996. Parasitic relationships between a gall forming insect Tomoplagia rudolphi (Diptera: Tephritidae) and its host plant (Vernonia polyanthes, Asteraceae). Annals of Botany, vol. 78 , p. 45-48.

SOUZA, ALT., TANAKA, MO., FERNANDES, GW. and FIGUEIRA, JEC., 2001. Host plant response and phenotypic plasticity of a galling weevil (Collabismus clitellae: Curculionidae). Austral Ecology, vol. 26, no. 2, p. 173-178.

WHITHAM, TG., MASCHINSKI, J., LARSON, KC. and PAIGE, NK., 1991. Plant response to herbivory: the continuum from negative to positive and underlying physiological mechanisms. In PRICE, PW., LEWINSOHN, TG., FERNANDES, GW. and BENSON, WW. Plant-animal interactions: evolutionary ecology in tropical and temperate regions. New York: Wiley. p. 227-256. vol. 1. 